\title{
Antigen-driven bystander effect accelerates epicutaneous sensitization with a new protein allergen Li-Fang Wang ${ }^{1}$ Jau-Shiuh Chen ${ }^{1}$, Chih-Jung Hsu ${ }^{1}$, Ching-Yi Liu ${ }^{1}$, Jhang- Sian $\mathrm{Yu}^{2}$ and Shi-Chuen Miaw*2
}

\author{
Address: ${ }^{1}$ Department of Dermatology, National Taiwan University Hospital and National Taiwan University College of Medicine, Taipei, Taiwan \\ and ${ }^{2}$ Graduate Institute of Immunology, National Taiwan University Hospital and National Taiwan University College of Medicine, Taipei, Taiwan \\ Email: Li-Fang Wang - lifangwa@ntu.edu.tw; Jau-Shiuh Chen - cjs0088@yahoo.com.tw; Chih-Jung Hsu - cz038@ms29.hinet.net; Ching- \\ Yi Liu - ek39.joyliu@msa.hinet.net; Jhang-Sian Yu - sky_hsiang@yahoo.com.tw; Shi-Chuen Miaw* - smiaw@ntu.edu.tw \\ * Corresponding author
}

Published: 6 March 2009

Journal of Biomedical Science 2009, 16:28 doi:10.1/86/1423-0I27-16-28

This article is available from: http://www.jbiomedsci.com/content/16/I/28

(c) 2009 Wang et al; licensee BioMed Central Ltd.

This is an Open Access article distributed under the terms of the Creative Commons Attribution License (http://creativecommons.org/licenses/by/2.0), which permits unrestricted use, distribution, and reproduction in any medium, provided the original work is properly cited.
Received: 22 December 2008

Accepted: 6 March 2009

\begin{abstract}
Exposure to protein allergen epicutaneously, inducing a Th2-dominant immune response, sensitizes the host to the development of atopic disease. Antigen-driven bystander effect demonstrates that polarized $T$ cells could instruct naïve $T$ cells to differentiate into $T$ cells with similar phenotype. In this study, we aimed to determine the contribution of antigen-driven bystander effect on epicutaneous sensitization with a newly introduced protein allergen. BALB/c mice were immunized intraperitoneally with BSA emulsified in alum, known to induce a Th2 response, three weeks before given BSA and OVA epicutaneously. Lymph node cells from these mice restimulated with OVA secreted higher levels IL-4, IL-5 and IL-I 3 as compared with cells from mice without BSA immunization. In addition, BALB/c mice immunized subcutaneously with BSA emulsified in complete Freund's adjuvant, known to induce a Thl-predominant response, also induced higher ThI as well as Th2 cytokine response when restimulated with OVA as compared with mice without immunization. We demonstrated that subcutaneous immunization with BSA in CFA induced Th2 as well as ThI response. The threshold of epicutaneous sensitization to OVA was also reduced, possibly due to increased expressions of IL-4 and IL- 10 in the draining lymph nodes during the early phase of sensitization. In conclusion, antigen-driven bystander effect, whether it is of ThI- or Th2predominant nature, can accelerate epicutaneous sensitization by a newly introduced protein allergen. These results provide a possible explanation for mono- to poly-sensitization spread commonly observed in atopic children.
\end{abstract}

\section{Background}

In the past several decades, there has been a progressive increase in the prevalence of atopic disease and an associated increase in the cost of medical management [1]. Atopic diseases are manifested as atopic dermatitis (AD), asthma, and allergic rhinitis. Atopy is associated with the expression of allergen-specific immune response characterized by the production of Th2 cytokines such as IL-4, IL-5, and IL-13; elevated IgE production; and eosinophilia. In contrast, non-atopic individuals display predominant Th1 immune response characterized by the production of IFN- $\gamma$. Genetics predisposition and expo- 
sure to various environmental allergens, which result in a Th2 immune response, contribute to the pathogenesis of atopic diseases [2].

$\mathrm{AD}$ is often the first clinical manifestation of an atopic triad and is the beginning of the "atopic march" [3]. However, the route of sensitization by an allergen that results in $\mathrm{AD}$ is still unclear. There is compelling evidence to show that epicutaneous exposure to a protein allergen is one of the important routes to sensitize the host for $\mathrm{AD}$ and other atopic diseases [4]. By the presence of cutaneous lymphocyte-associated antigen (CLA)-positive T cells, it is shown in humans, that $\mathrm{T}$ cells are primed or reactivated in the skin or its draining lymph nodes (LNs) $[5,6]$. In $\mathrm{AD}$ patients, the increased frequency of prior activation and secretion of type 2 cytokines, as well as higher proliferation response to allergen, are largely confined to a CLApositive subset [7-9]. Moreover, T cell receptor skewing is only detectable within the CLA-positive subset of T cells from those subjects from whom superantigen-secreting, skin-dwelling bacteria could be identified [10]. The recent demonstration of the expression of CLA by CD8 T cells specific for a skin-tropic, but not non-skin-tropic, virus further supports this concept [11]. We and others have demonstrated in an atopic dermatitis animal model, that epicutaneous exposure of protein antigen induces a predominant Th2 response with high IgE production $[12,13]$. Furthermore, epicutaneous sensitization with protein antigen induces AD-like skin lesions and development of asthma [14]. The epicutaneously-induced Th2 response requires IL-10 and IL-13 [15,16], while down-regulation of the response is mediated by C3a, cyclooxygenase- 2 , and skin scratching [17-19].

It has been demonstrated that through an antigen-driven bystander effect, polarized $\mathrm{T}$ cells instruct naïve $\mathrm{T}$ cells to differentiate into $\mathrm{T}$ cells with a similar phenotype. This bystander effect is observed only when the challenge inoculum contains both the original antigen and a newly introduced antigen. This effect was initially shown to be a mechanism of antigen-driven peripheral tolerance after oral administration of antigens, and it can protect rats from developing experimental autoimmune encephalomyelitis [20]. Adoptive co-transfer of two populations of $\mathrm{T}$-cell receptor transgenic $\mathrm{T}$ cells of different specificities demonstrated that polarized Th1 or Th2 effector cells can instruct naïve T cells to differentiate into Th1 or Th2 cells, respectively [21]. Subsequently, study of a murine asthma model revealed that an ongoing Th2 response can induce antigen-specific Th2 response to a new antigen, a process termed "collateral priming" [22]. Further exploration of the underlying mechanisms of the antigen-driven bystander effect has demonstrated that conversion of a naïve $\mathrm{T}$ cell occurs only when it interacts with the same $\mathrm{APC}$ as the memory T cell, and that the orally immunized memory T cells use IL-4 and IL-10 to "educate" APCs, which in turn induce naïve $T$ cells to produce the same cytokines as those produced by the orally immunized memory $\mathrm{T}$ cells [23]. In this present study, we demonstrated that antigen-driven bystander effect, despite its Th1- or Th2-predominant nature, accelerates epicutaneous sensitization with a new protein antigen.

\section{Materials and methods Mice and reagents}

Six to 10-week-old female BALB/C and TCR-OVADO11.10 mice were purchased from the animal center of National Taiwan University Collage of Medicine and kept in a specific pathogen-free environment. All animal experiments were approved by the animal care committee of the Medical College of National Taiwan University. OVA (Grade V), BSA, CFA, and 4-nitrophenyl phosphate (pNPP) were purchased from Sigma-Aldrich (St. Louis, $\mathrm{MO}$ ). Alum adjuvant was purchased from Pierce (Rockford, IL) and carboxyfluorescein succinimidyl ester (CFSE) was obtained from Invitrogen (Carlsbad, CA). Capture and biotin-conjugated detecting antibodies for IFN- $\gamma$, IL-4, IL-5 used in the ELISA were from PharMingen (San Diego, CA). Streptavidine-alkaline phosphatase was purchased from Southern Biotechnology (Birmingham, $\mathrm{AL}$ ). The murine IL-13 ELISA kit purchased from R\&D systems (Minneapolis, MN) was used for determination of the IL-13 content of supernatants.

\section{Sensitization}

Mice were sensitized as previously described [24]. Briefly, $20 \mu \mathrm{l}$ of OVA $(100 \mathrm{mg} / \mathrm{ml}$ or serial dilutions) and $20 \mu \mathrm{l}$ of BSA $(100 \mathrm{mg} / \mathrm{ml})$ were placed on the disc of a Finn chamber (Epitest, Tuusula, Finland). This was then applied to an area of shaved skin on the back of a mouse. For each course of sensitization, freshly prepared patches were applied daily from days 1 to 5. For pretreatment, mice received a subcutaneous (s.c.) injection of $100 \mu \mathrm{g}$ BSA emulsified in CFA over the bilateral side of tail-base or an intraperitoneal (i.p.) injection of $100 \mu \mathrm{g}$ BSA in alum adjuvant three weeks before sensitization.

\section{Adoptive transfer}

For adoptive transfer of OVA-TCR CD4 T cells, spleen cells from DO.11.10 mice were positively selected for CD4 T cells using CD4 microbeads. Then, $10^{7} \mathrm{CD} 4 \mathrm{~T}$ cells $/ \mathrm{ml}$ were incubated with $1 \mu \mathrm{M}$ CFSE for $10 \mathrm{~min}$ at $37^{\circ} \mathrm{C}$. Prewarmed FCS-containing PBS was added and washed by cold PBS. Labeled OVA-TCR CD4 T cells $\left(5 \times 10^{6}\right)$ were intravenously injected into BALB/C recipients $24 \mathrm{~h}$ before sensitization.

\section{LN and spleen cell cytokine production and proliferation assay}

Ten days after the start of a sensitization course, mice were sacrificed to obtain axillary, subscapular, and inguinal LNs. Pooled LN cells $\left(1 \times 10^{6}\right)$ were cultured in the pres- 
ence or absence of $100 \mu \mathrm{g} / \mathrm{ml}$ OVA. Supernatants were harvested $48 \mathrm{~h}$ later and stored at $-80^{\circ} \mathrm{C}$. IFN- $\gamma$, IL-4, IL-5, and IL-13 content of supernatants was each measured by a standard sandwich ELISA. The limit of detection for IL4, IL-5, and IL-13 were all $10 \mathrm{pg} / \mathrm{ml}$, whereas that for IFN$\gamma$ was $50 \mathrm{pg} / \mathrm{ml}$. For spleen cells, spleens were harvested 3 weeks after sensitization, and pooled spleen cells were stimulated with $100 \mu \mathrm{g} / \mathrm{ml}$ OVA. For the proliferation assay, graded doses of OVA were added. $48 \mathrm{~h}$ after the initiation of culture, $\left[{ }^{3} \mathrm{H}\right]$ thymidine was added and the cells were harvested $18 \mathrm{~h}$ later.

\section{Total RNA extraction, cDNA preparation and quantitative real-time $P C R$}

The patched skin and draining lymph node samples were obtained 24, 48, and $72 \mathrm{~h}$ after patch co-administration of BSA and OVA. They were frozen with liquid nitrogen and soaked in $1 \mathrm{ml}$ TRIzol Reagent (Invitrogen, Carlsbad, CA, USA). After homogenization, the total RNA was extracted, cDNA was synthesized, and quantitative real-time PCR was performed according to the manufacturer's instructions. Each sample was analyzed in triplicate. The relative cytokine mRNA expression level of each sample was normalized according to its $\beta$-actin expression.

\section{Results}

Antigen-driven bystander effect enhances epicutaneouslyinduced Th2 immune response to a co-administered new protein allergen

Murine protein-patch model has been established by us and others to study immune responses induced by epicutaneous sensitization with protein antigens $[12,14]$. It has been shown in previous studies that patch application of OVA solution onto mouse skin induces a predominant Th2 and a weak Th1 immune response. To investigate whether polarized Th2 cells could influence the immune response induced by epicutaneous sensitization with a newly introduced protein antigen, mice were immunized with BSA emulsified in alum adjuvant through the intraperitoneal route and were exposed to both OVA and BSA epicutaneously by patch application three weeks later. Data in Fig. 1A show that LN cells from mice previously immunized with BSA and restimulated with OVA produced significantly higher IL-4, IL-5, and IL-13 in the culture supernatants as compared with cells from mice that did not receive BSA immunization. There was no difference in IFN- $\gamma$ production between mice receiving immunization and those that did not. Interestingly, when BSA was omitted from the patch, the enhanced Th2 response

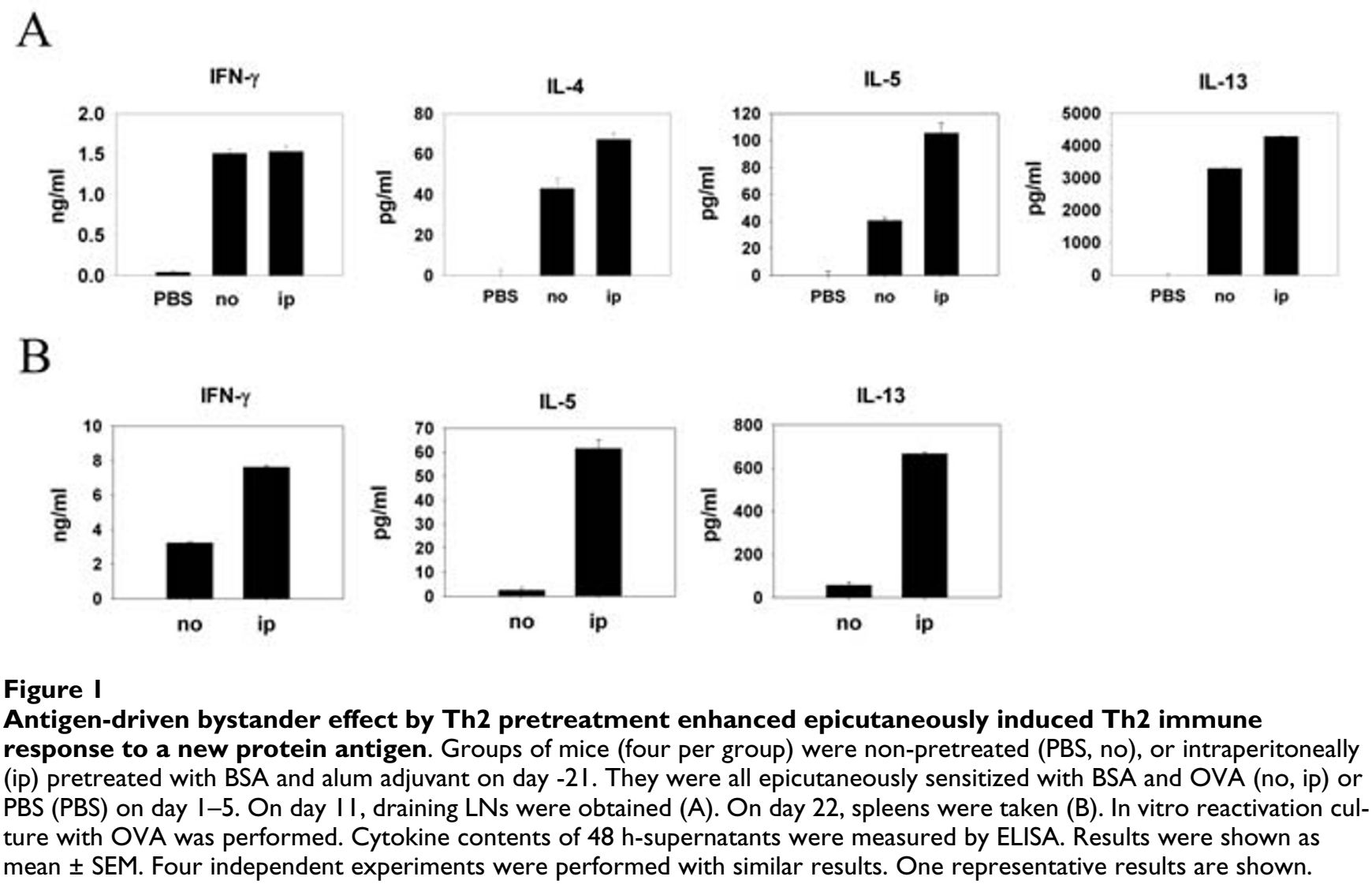


was no longer observed (data not shown). These results indicate that enhanced Th2 cytokine production was induced by antigen-driven bystander effect. We further tested whether spleen cells also mounted an enhanced Th2-dominant response at a later time point. Splenocytes from mice immunized with BSA and sensitized epicutaneously with OVA and BSA were restimulated with OVA. Fig. $1 \mathrm{~B}$ shows that splenocyte IL-5 and IL-13 productions were much higher than those from the mice without immunization. However, OVA-specific IL-4 production was not detected in the spleen cell cultures. Next, we tested the antigen-driven bystander effect of polarized Th1 cells. Subcutaneous injection of protein antigen emulsified in CFA adjuvant is a standard way to induce Th1-predominant immune response in experimental murine system. $\mathrm{BALB} / \mathrm{c}$ mice were immunized subcutaneously with BSA emulsified in CFA or not three weeks before epicutaneous sensitization with OVA plus BSA. LN cells from mice receiving subcutanous immunization of BSA and patchsensitized with BSA and OVA produced not only higher concentrations of IFN- $\gamma$, but also IL-4, IL-5 and IL-13 in the culture supernatants after restimulation with OVA as compared to cells from unimmunized mice (Fig. 2A). In the meantime, the splenocyte IL-5 and IL-13 but not IFN$\gamma$ productions were much higher than those from the mice without immunization (Fig. 2B). Mice immunized subcutaneously also had higher levels of serum OVA-specific IgG2a and IgE in the serum (Fig. 2C) than the mice without immunization, although they did not reach statistical significance. As shown in Fig. 2D, subcutaneous immunization with BSA in CFA adjuvant induced both Th1 and Th2 immune responses, indicated by high concentrations of IFN- $\gamma$ as well as significant amounts of IL-4, IL-5, and IL-13. Taken together, despite its Th1/Th2 predominant nature, the antigen-driven bystander effect enhances the Th2 immune response induced by an epicutaneously introduced new protein antigen.

\section{Antigen-driven bystander effect decreases the threshold of epicutaneous sensitization with a new protein allergen}

The next question was whether the antigen-driven bystander effect could modulate the threshold of epicutaneous sensitization with a new protein allergen. LN cells from mice receiving subcutaneous or intraperitoneal immunization with BSA had higher proliferative response to OVA after patch sensitization with both BSA and OVA as compared with those without immunization (Fig. 3A). Next, serial dilutions of OVA were co-administered with a fixed concentration of BSA to explore whether immunization modulates the threshold of epicutaneous sensitization to OVA in this model system. LN cells from mice subcutaneously immunized with BSA had higher proliferative response to OVA than mice without immunization when OVA was co-administered at concentrations of 100 $\mathrm{mg} / \mathrm{ml}, 10 \mathrm{mg} / \mathrm{ml}$ or $1 \mathrm{mg} / \mathrm{ml}$ with BSA. Without immu- nization, OVA co-administered at $100 \mathrm{mg} / \mathrm{ml}$ and $10 \mathrm{mg} /$ $\mathrm{ml}$ but not at $1 \mathrm{mg} / \mathrm{ml}$ with BSA induced cells to respond specifically to OVA stimulation (Fig. 3B). To examine CD4 $\mathrm{T}$ cell proliferation in vivo, CD4 T cells from naïve OVA-TCR transgenic mice (DO11.10) were labeled with CFSE and intravenously transferred into BALB/c mice one day before they received patch co-sensitization with OVA and BSA. Fig. 3C shows that transgenic CD4 T cells proliferated in mice subcutaneously immunized with BSA and sensitized epicutaneously with $10 \mathrm{mg} / \mathrm{ml}$ and $100 \mathrm{mg} / \mathrm{ml}$ OVA plus BSA, and adoptively transferred transgenic CD 4 $\mathrm{T}$ cells had proliferative response only in unimmunized mice patched with $100 \mathrm{mg} / \mathrm{ml}$ OVA (Fig. 3C). Collectively, these data support the notion that the antigendriven bystander effect decreases the threshold of epicutaneous sensitization with a new protein allergen by at least one order of magnitude.

\section{The role of cytokines in epicutaneously induced antigen- driven bystander effect}

Among the cytokines that influence the Th1/Th2 balance, IFN- $\gamma$, IL-12 and IL-18 are the key cytokines to induce Th1 responses, while IL-4, IL-10 and IL-13 preferentially prime Th2 responses. Figure 4 shows that mice receiving subcutaneous immunization had higher levels of IL-4 and IL-10 expression in their draining LNs as early as $24 \mathrm{~h}$ after patch sensitization as compared with mice without immunization. The expressions of other cytokines, including IL-5, IL-12, IL-13, IL-18, IFN- $\gamma$ and TNF- $\alpha$, in the draining LNs were similar in mice with or without immunization. It is noteworthy, the expressions of all of these cytokines in the patch-applied skin were not different between mice with or without immunization groups (data not shown). Taken together, these results suggest that immunization-induced IL-4 and IL-10 expression contributes to the epicutaneously induced antigen-driven bystander effect.

\section{Discussion}

The data presented here clearly demonstrate that the antigen-driven bystander effect, despite its Th1- or Th2-predominant nature, accelerates epicutaneous sensitization with a new protein allergen by enhancing the Th2 immune response and by lowering the sensitization threshold. To our knowledge, this is the first report to address the contribution of antigen-driven bystander effect to the epicutaneous sensitization of protein allergens in atopic disease.

The continuation of fetal allergen-specific Th2 responses associated with decreased capacity to produce Th1 cytokine IFN- $\gamma$ is a defining feature of atopic disease in infancy [25]. After infancy, the major sensitized allergens shift from oral food allergens to aeroallergens [26]. Several observations are consistent with the view that some 
A
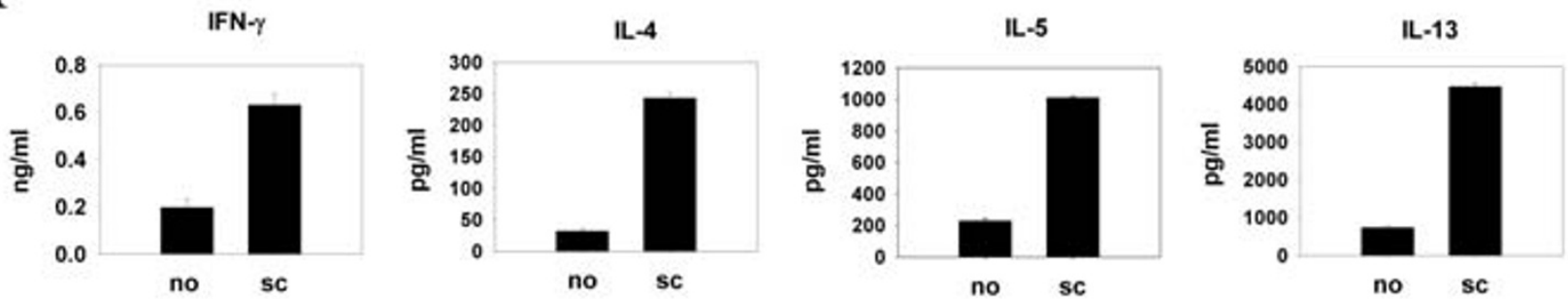

B
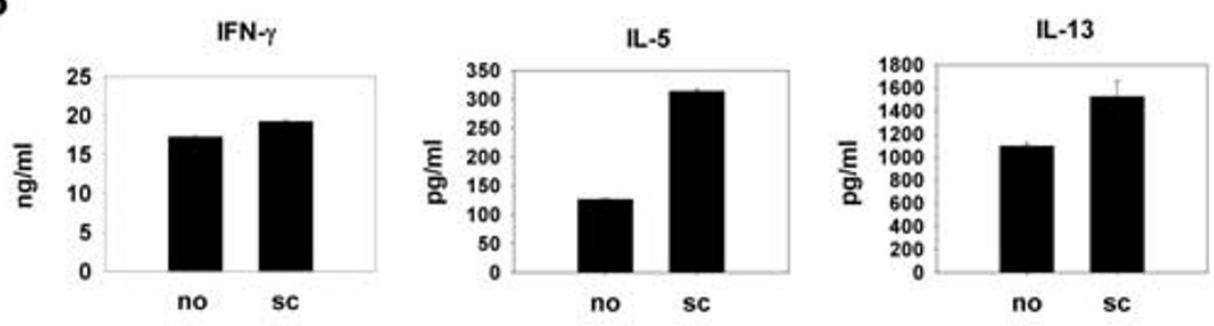

C
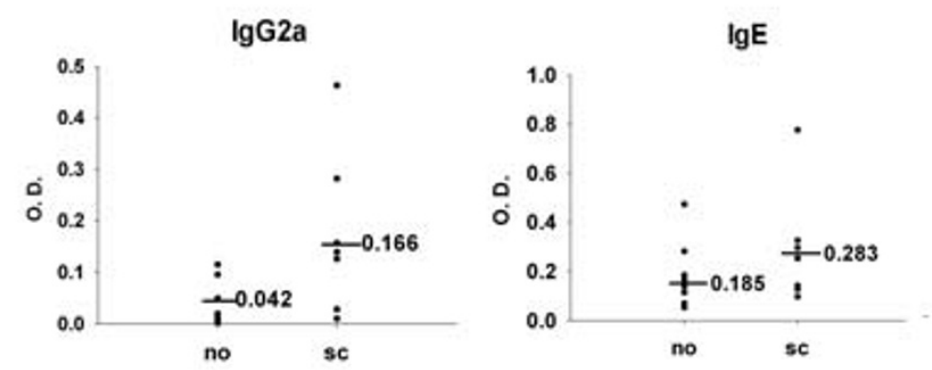

D
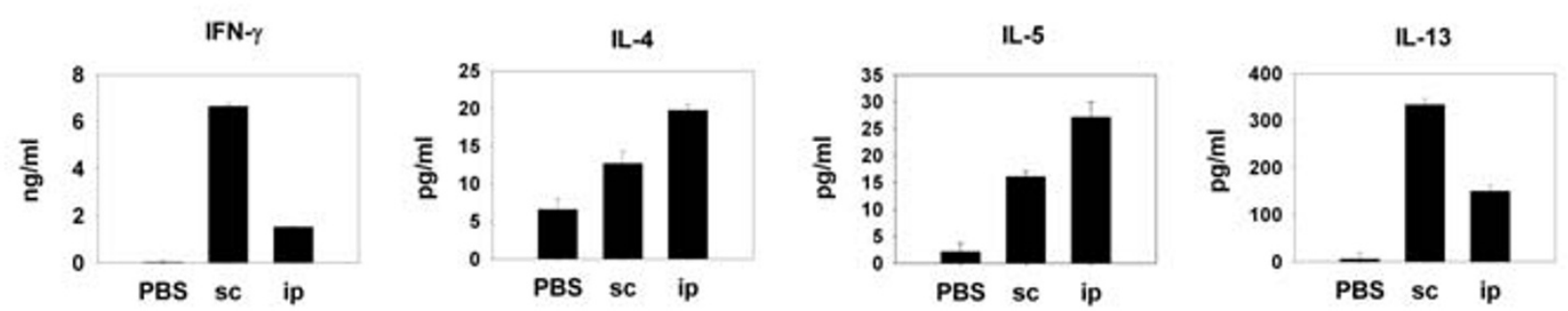

Figure 2

Antigen-driven bystander effect by ThI pretreatment also enhanced epicutaneously induced Th2 immune response to a new protein antigen. (A) (B) (C) Group of mice (Four per group) were non-pretreated (PBS, no) or subcutaneously (sc) pretreated with BSA and CFA adjuvant on day -2I. They were all epicutaneously sensitized with BSA and OVA (no, sc) or PBS (PBS) on day I-5. On day II, draining LNs were obtained (A). On day 22 spleens were taken (B). In vitro reactivation culture with OVA was performed. Cytokines contents of $48 \mathrm{~h}$-supernatants were measured by ELISA. Results were shown as mean \pm SEM. (C) On day 22 26, all mice received another course of OVA patch application. On day 29, blood were collected and serum OVA-specific IgG2a and IgE were determined by ELISA. Three independent experiments were performed with similar results. One representative results are shown. (D) Groups of mice (four per group) were immunized by subcutaneous injection with BSA and CFA adjuvant (sc) or BSA and alum adjuvants (ip) three weeks before their spleens were obtained. In vitro reactivation culture of spleen cells with BSA was performed. Cytokine contents of $48 \mathrm{~h}$-supernatants were measured by ELISA. Results were shown as mean \pm SEM. Three independent experiments were performed with similar results. One representative results are shown. 
A

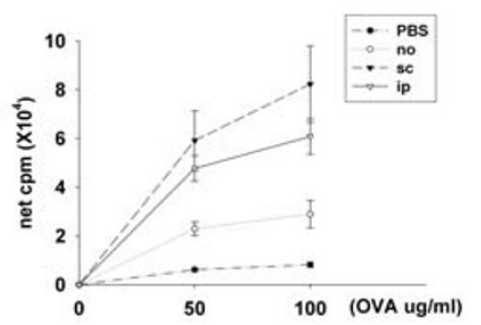

B

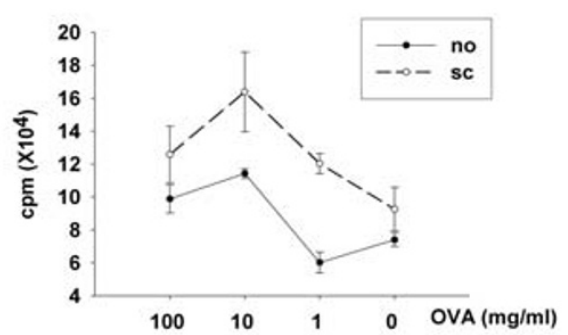

C
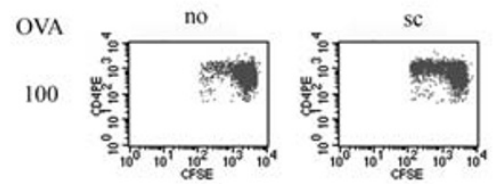

10
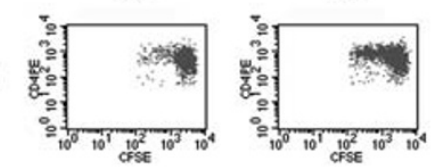

1
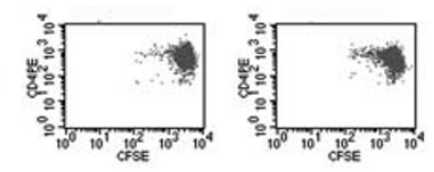

\section{Figure 3}

Influence of antigen-driven bystander effect on the threshold of epicutaneous sensitization with a new protein allergen. (A) Groups of mice (four per group) were similarly pretreated and immunized as in Fig. I (A). On day II, draining LNs were obtained and OVA-specific proliferation assay was performed. (B) Groups of mice (four per group) were subcutaneously pretreated with BSA (sc) or not (no) on day -21 . They received patch co-administration of serial dilutions of OVA $(100,10,1 \mathrm{mg} / \mathrm{ml})$ and BSA $(100 \mathrm{mg} /$ $\mathrm{ml}$ ) on day I-5. On day II, draining LNs were obtained and OVA-specific proliferation assay was performed. (C) Groups of mice (four per group) were non-pretreated (no) or subcutaneously (sc) pretreated on day -2I. One day before patch application, all mice received i.v. transfer of CFSE-labeled CD4 T cells prepared from DOII.IO transgenic mice. Patch application with serial dilutions of OVA $(100,10,1 \mathrm{mg} / \mathrm{ml})$ and BSA $(100 \mathrm{mg} / \mathrm{ml})$ were performed on day I-3. Regional LNs were obtained on day 4 for staining and flow cytometric analysis. All experiments were performed independently for at least three times. One representative results are shown. factors might modulate the susceptibility to allergen sensitization. Firstly, the dose-response relationship between allergen exposure and sensitization differs depending on allergens and locales [27]. Secondly, once sensitized to one allergen, atopic patients are more likely to become sensitized to other allergens [28]. Moreover, there are strong associations of multiple sensitizations both within and between different allergen classes [28]. Skin is continuously exposed to many kinds of allergens and microorganisms in the environment. Microorganisms can gain access to the human body through different routes and sensitize the immune system before contact with the skin. Therefore, it is very likely that the antigen-driven bystander effect affects our skin constantly, although its effect may vary. Thus, the present study provides a possible mechanistic explanation to the clinical observation of the spread of Th2 responses from mono-allergen to multiple allergens in atopic individuals. Another clinical implication of our data is that our results do not conflict with "hygiene hypothesis". The "hygiene hypothesis" predicts that nonspecific suppression of Th2 immune response by a predominant systemic Th 1 milieu at the time of sensitization prevents the development of allergy. However, our present study demonstrated specific, but not non-specific, promotion of Th2 immune responses by antigen-driven bystander effect. Collectively, our results support the wisdom of recognizing allergen sensitization early in life and taking precautions to prevent exposure of skins to these allergens.

The mechanism underlying the antigen-driven bystander effect is still obscure. Alpan et al. suggests that orally induced memory $\mathrm{T}$ cells utilize IL- 4 and IL-10 they produced, but not CD40 ligand, to educate DCs which in turn induce conversion of naïve T cells [23]. However, since coculturing DCs with naïve T cells plus various concentrations of IL-4 and IL-10 does not simulate the situation in which DC was educated by orally induced memory $\mathrm{T}$ cells in their studies, the authors suggested that there must be other factors involved [23]. Our current study provides more information about the underlying mechanism of antigen-driven bystander effect. As we demonstrated in this report, systemic immunization plus skin sensitization to protein antigens induce increased cytokine expression in the draining LNs, but not in the patched skin. This observation supports the notion that the draining LNs are the site where antigen-driven bystander effect takes place [29].

In summary, in this study we demonstrated that antigendriven bystander effect contributes to accelerated epicutaneous sensitization with a new protein allergen. These results provide a possible explanation for a mono- to poly-sensitization spread commonly observed in atopic children. 
IL-4

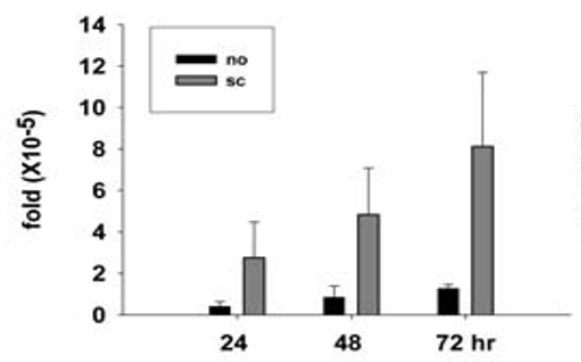

IL-5

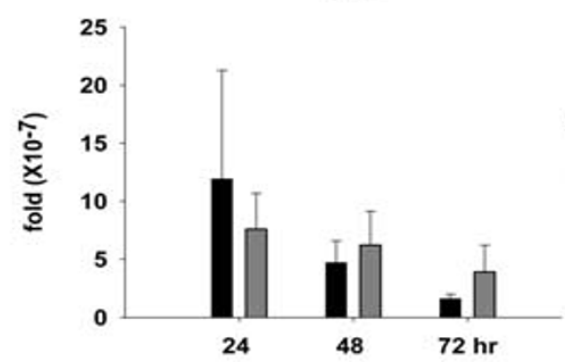

IL-13

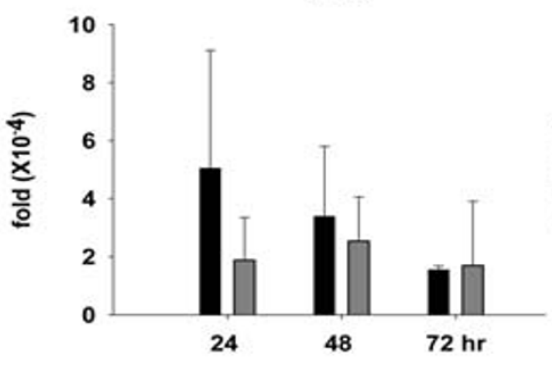

IFN- $\gamma$

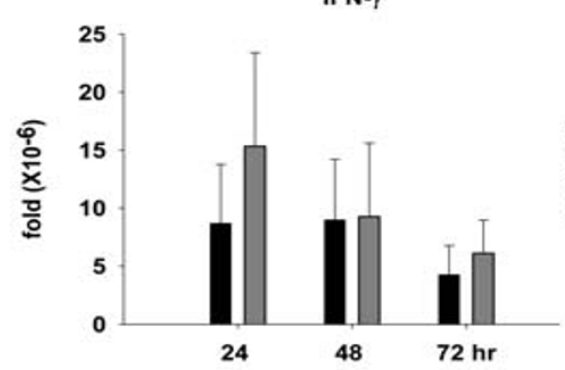

IL-10

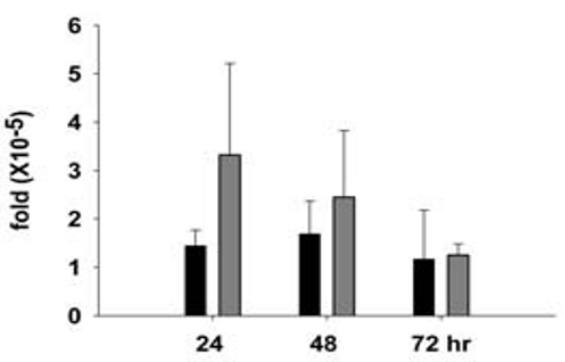

IL-12

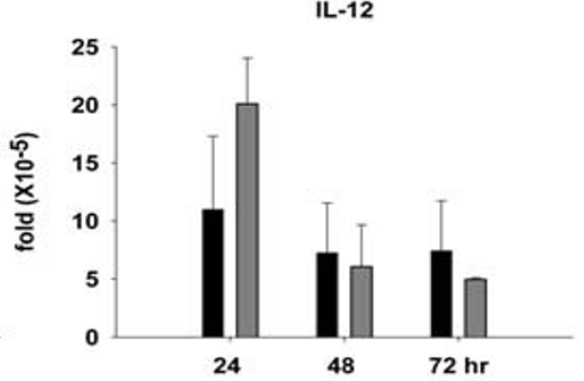

IL-18
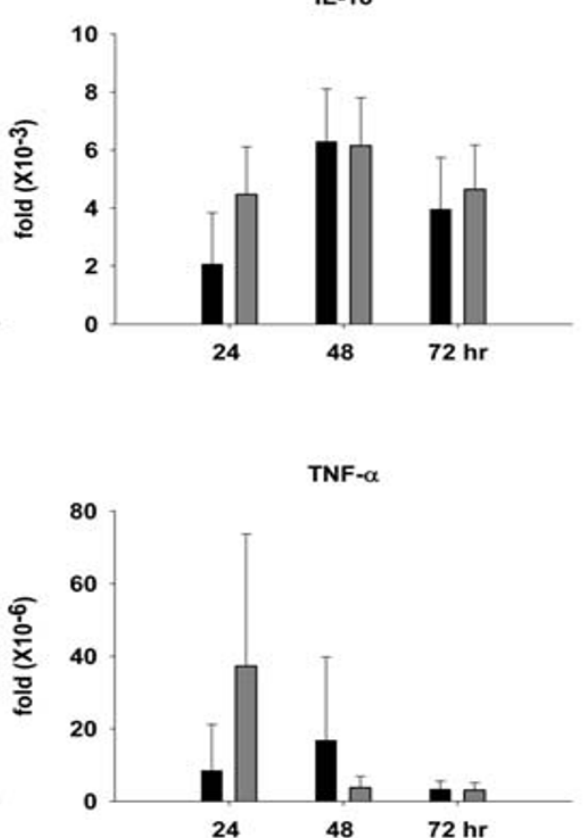

Figure 4

The role of cytokine in the epicutaneously induced antigen-driven bystander effect. Groups of mice (three per group) were non-pretreated (no) or pretreated subcutaneously with BSA and CFA adjuvant (sc) three weeks before they received patch sensitization with OVA and BSA on day I-3. Draining LNs were obtained 24, 48 and $72 \mathrm{hr}$ after start of patch sensitization. Total RNA extraction, cDNA preparation and quantitative real-time PCR were performed individually. The relative cytokine mRNA expression levels of each sample were normalized according to its $\beta$-actin expression. Results are shown as mean \pm SEM. Three independent experiments were performed with similar results. One representative results are shown. 


\section{Abbreviations}

AD: atopic dermatitis; LN: lymph node; CLA: cutaneous lymphocyte-associated antigen.

\section{Competing interests}

The authors declare that they have no competing interests.

\section{Authors' contributions}

LFW, JSC, CJH and SCM participated in the design of the study and preparation of the manuscript. JSY carried out the measurement of cytokine mRNA expression. CYL performed all other experiments.

\section{Acknowledgements}

We thank Dr. Betty A. Wu-Hsieh for helpful advice and careful review of the manuscript. This work was supported by grants from National Taiwan University Hospital (94N049, 94A I8-4 and 95A2I-4) and from National Health Research Institutes (NHRI-EX95-95I6SC).

\section{References}

I. Sublett JL: The environment and risk factors for atopy. Current allergy and asthma reports 2005, 5(6):445-450.

2. Allam J-P, Bieber T, Novak N: Recent Highlights in the pathophysiology of atopic eczema. Int Arch Allergy Appl Immunol 2005 136:191-197.

3. Spergel JM, Paller AS: Atopic dermatitis and the atopic march. J Allergy Clin Immunol 2003, I I 2(6, Supplement I):SI I 8-SI 27.

4. Berard F, Marty J-P, Nicolas J-F: Allergen penetration through the skin. Eur J Dermatol 2003, 13(4):324-330.

5. Picker LJ, Treer JR, Ferguson-Darnell B, Collins PA, Bergstresser PR Terstappen LWMM: Control of lymphocyte recirculation in man. II. Differential regulation of the cutaneous lymphocyteassociated antigen, a tissue-selective homing receptor for skin-homing T cells. J Immunol I993, I 50(3): I I 22- I I 36.

6. Hunger RE, Yawalkar N, Braathen LR, Brand CU: The HECA-452 epitope is highly expressed on lymph cells derived from human skin. $\mathrm{Br}$ J Dermatol I999, I 4 I(3):565-569.

7. Santamaria Babi LF, Picker LJ, Perez Soler MT, Drzimalla K, Flohr P, Blaser K, Hauser C: Circulating allergen-reactive $\mathbf{T}$ cells from patients with atopic dermatitis and allergic contact dermatitis express the skin-selective homing receptor, the cutaneous lymphocyte-associated antigen. J Exp Med 1995, 181(5): 1935-1940.

8. Teraki $Y$, Hotta T, Shiohara T: Increased circulating skin-homing cutaneous lymphocyte-associated antigen (CLA)+ type 2 cytokine-producing cells, and decreased CLA+ type I cytokine-producing cells in atopic dermatitis. $\mathrm{Br} J$ Dermatol 2000, I 43(2):373-378.

9. Seneviratne SL, Jones L, King AS, Black A, Powell S, McMichael AJ, Ogg GS: Allergen-specific CD8+ T cells and atopic disease. J Clin Invest 2002, I I0(9): |283-I29|.

10. Strickland I, Hauk PJ, Trumble AE, Picker LJ, Leung DYM: Evidence for Superantigen Involvement in Skin Homing of $T$ cells in Atopic Dermatitis. J Invest Dermatol I999, I I 2(2):249-253.

II. Koelle DM, Liu Z, McClurkan CM, Topp MS, Riddell SR, Pamer EG, Johnson AS, Wald A, Corey L: Expression of cutaneous lymphocyte-associated antigen by CD8+ $T$ cells specific for a skin-tropic virus. / Clin Invest 2002, I I 0(4):537-548.

12. Wang LF, Lin JY, Hsieh KH, Lin RH: Epicutaneous exposure of protein antigen induces a predominant Th2-like response with high IgE production in mice. I Immunol 1996, I 56(I I):4077-4082.

13. Kondo H, Ichikawa $Y$, Imokawa G: Percutaneous sensitization with allergens through barrier-disrupted skin elicits a Th2dominant cytokine response. Eur J Immunol I998, 28(3):769-779.

14. Spergel JM, Mizoguchi E, Brewer JP, Martin TR, Bhan AK, Geha RS: Epicutaneous sensitization with protein antigen induces localized allergic dermatitis and hyperresponsiveness to methacholine after single exposure to aerosolized antigen in mice. J Clin Invest 1998, I0 (8):1614-1622.
15. Laouini D, Alenius H, Bryce P, Oettgen H, Tsitsikov E, Geha RS: IL10 is critical for Th2 responses in a murine model of allergic dermatitis. J Clin Invest 2003, I I 2(7): I058- 1066.

16. Herrick CA, Xu L, McKenzie ANJ, Tigelaar RE, Bottomly K: IL-I3 is necessary, not simply sufficient, for epicutaneously induced Th2 responses to soluble protein antigen. I Immunol 2003, I 70(5):2488-2495.

17. Kawamoto S, Yalcindag A, Laouini D, Brodeur S, Bryce P, Lu B, Humbles AA, Oettgen H, Gerard C, Geha RS: The anaphylatoxin C3a downregulates the Th2 response to epicutaneously introduced antigen. J Clin Invest 2004, I I4(3):399-407.

18. Laouini D, ElKhal A, Yalcindag A, Kawamoto S, Oettgen H, Geha RS: COX-2 inhibition enhances the TH2 immune response to epicutaneous sensitization. J Allergy Clin Immunol 2005, I I6(2):390-396.

19. Matsushima H, Hayashi S, Shimada S: Skin scratching switches immune responses from Th2 to ThI type in epicutaneously immunized mice. J Dermatol Sci 2003, 32(3):223-230.

20. Miller A, Lider O, Weiner HL: Antigen-driven bystander suppression after oral administration of antigens. J Exp Med I99|, I74(4):79|-798.

21. Creusot RJ, Biswas JS, Thomsen LL, Tite JP, Mitchison NA, Chain BM: Instruction of naive CD4+ T cells by polarized CD4+ T cells within dendritic cell clusters. Eur J Immunol 2003, 33(6): 1686-1696

22. Eisenbarth SC, Zhadkevich A, Ranney P, Herrick CA, Bottomly K: IL4-dependent Th2 collateral priming to inhaled antigens independent of Toll-like receptor 4 and myeloid differentiation factor 88. J Immunol 2004, 172(7):4527-4534.

23. Alpan O, Bachelder E, Isil E, Arnheiter H, Matzinger P: 'Educated' dendritic cells act as messengers from memory to naive $T$ helper cells. Nat Immunol 2004, 5(6):6I5-622.

24. Wang L-F, Hsu C-J, Miaw S-C, Chiu H-C, Liu C-Y, Yu H-S: Crosspriming with an epicutaneously introduced soluble protein antigen generates Tcl cells. Eur J Immunol 2006, 36(II):2904-29II.

25. Prescott SL, Macaubas C, Smallacombe T, Holt BJ, Sly PD, Holt PG Development of allergen-specific T-cell memory in atopic and normal children. Lancet 1999, 353:196-200.

26. Kulig M, Bergmann R, Klettke U, Wahn V, Tacke U, Wahn U: Natural course of sensitization to food and inhalant allergens during the first 6 years of life. I Allergy Clin Immunol 1999, 103(6): $1173-1179$.

27. Torrent M, Sunyer J, Munoz L, Cullinan P, Iturriaga MV, Figueroa $C$, Vall O, Taylor AN, Anto JM: Early-life domestic aeroallergen exposure and IgE sensitization at age 4 years. J Allergy Clin Immunol 2006, II 8(3):742-748.

28. Roberts G, Peckitt C, Northstone K, Strachan D, Lack G, Henderson J, Golding J: Relationship between aeroallergen and food allergen sensitization in childhood. Clin Exp Allergy 2005, 35(7):933-940.

29. Schipf A, Heilmann A, Boue L, Mossmann H, Brocker T, Rocken M: Th2 cells shape the differentiation of developing $T$ cell responses during interactions with dendritic cells in vivo. Eur J Immunol 2003, 33(6): 1697-1706.

Publish with Bio Med Central and every scientist can read your work free of charge

"BioMed Central will be the most significant development for disseminating the results of biomedical research in our lifetime. "

Sir Paul Nurse, Cancer Research UK

Your research papers will be:

- available free of charge to the entire biomedical community

- peer reviewed and published immediately upon acceptance

- cited in PubMed and archived on PubMed Central

- yours - you keep the copyright
BioMedcentral 